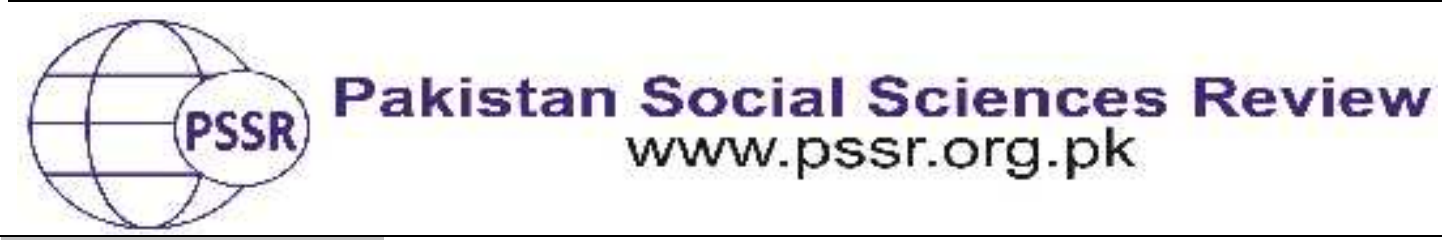

RESEARCH PAPER

\title{
Changing characteristics of Legal Education in Pakistan: Prospects and Challenges
}

\author{
Dr. Sardar M.A. Waqar Khan Arif ${ }^{1}$ Professor Dr. Muhammad Mahroof Khan ${ }^{2}$ \\ Bushra Bannian ${ }^{3}$
}

1. Head of Department, Department of Law, Faculty of Social Sciences and Humanities, University of Kotli, Azad Jammu and Kashmir, Pakistan

2. Dean, Faculty of Social Sciences and Humanities, University of Kotli, Azad Jammu and Kashmir, Pakistan

3. Lecturer, Department of Law, Faculty of Social Sciences and Humanities, University of Kotli, Azad Jammu and Kashmir, Pakistan

\begin{tabular}{|c|c|}
\hline PAPER INFO & BSTRACT \\
\hline $\begin{array}{l}\text { Received: } \\
\text { November 01, } 2019 \\
\text { Accepted: } \\
\text { December 25, } 2019 \\
\text { Online: } \\
\text { December 31, } 2019 \\
\end{array}$ & $\begin{array}{l}\text { This paper focuses on changing characteristics of legal } \\
\text { education in Pakistan. After independence, several institutions } \\
\text { were established in Pakistan for imparting legal education. is } \\
\text { well established that the supremacy of rule of law and justice is } \\
\text { pre-requisite for development in any state and it can be }\end{array}$ \\
\hline $\begin{array}{l}\text { Keywords: } \\
\text { Bar and Bench, } \\
\text { Legal Education, } \\
\text { Pakistan Bar } \\
\text { Council, } \\
\text { Pakistan's Legal } \\
\text { System }\end{array}$ & $\begin{array}{l}\text { strengthened and ensured by the concerned belonging to legal } \\
\text { arena, such as, Bar and Bench and academicians. The regulatory } \\
\text { authorities for imparting legal education are Higher Education } \\
\text { Commission (HEC) and Pakistan Bar Council (PBC). In } \\
\text { Pakistan, the recent Judgment of Supreme Court is significant } \\
\text { for legal reforms as it proclaims serious measures for } \\
\text { improvement in legal education. It concludes that still there is }\end{array}$ \\
\hline $\begin{array}{l}\text { *Corresponding } \\
\text { Author } \\
\text { sardarwaqarkhan } \\
\text { @gmail.com }\end{array}$ & $\begin{array}{l}\text { room for further improvement even after implementation of the } \\
\text { Judgment in its true sense.It recommends that further legal } \\
\text { reforms are needed for improvement in legal education. Finally, } \\
\text { conclusions and Recommendations will be given. }\end{array}$ \\
\hline
\end{tabular}

\section{Introduction}

Legal education in Pakistan is gradually deteriorated in terms of its quality. As noted down by the August Supreme Court (SC) in Pakistan Bar Council v. Federation ofPakistan (PLD 2007 SC 394). The Court has highlighted the importance of quality education and observed that: "The poor quality of legal education in the country is taking its toll onthe Bench, the Bar and ultimately the quality of justice".

Without having legal education, it is difficult for people to aware of their basic rights. This concept also links with the administration of Justice. The provisions of national as well as international law proclaims for administration of Justice within County. For instance, access to justice is guaranteed under article 8 and 10 of the 
Universal Declaration of Human Rights 1948 (UDHR, 1948) and article 10 of the International Covenant on Civil and Political Rights 1966 (ICCPR, 1966).

In terms of regional efforts towards administration of justice, various instruments recognize fair judicial system for seeking remedies within that region. The Committees are also formed to address grievances of the people, such as, Human rights Committee (HRC) as a treaty body of ICCPR. The Constitution of Islamic Republic of Pakistan 1973 (Constitution 1973) envisages provisions regarding quality education as well as administration of Justice within country. For example, it recognizes the independence of judiciary (Preamble Constitution, 1973), and its separation from the Executive (Art. 175 (3) of Constitution, 1973). The Constitution 1973 also obliges stats to "ensure inexpensive and expeditious justice" (Art. 37 (d) of Constitution, 1973). It is difficult to seek remedy from Court of law without possessing qualification and experience in relation to law. These qualities are linked with legal education.

The low level of quality education within country demands special attention to be paid. The quality of education links with country's education policy. The founder of Pakistan has stated that: "You know that the importance of education and the right type of education cannot beover-emphasized. Under foreign rule for over a century, in the very nature of things, Iregret, sufficient attention has not been paid to the education of our people, and if weare to make any real, speedy and substantial progress, we must earnestly tackle thisquestion and bring our educational policy and programme on the lines suited to thegenius of our people, consonant with our history and culture, and having regard to themodern conditions and vast developments that have taken place all over the world"(All- Pakistan Educational Conference, 27th November, 1947).

The quality education is dependent upon educational policies, role of the institutions, regulatory authoritiesand concerned. Pakistan is signatory to International instruments and in this regard, it has obligations as well. While legal education is professional and adult learning it is necessary to design curriculum of legal education in well manner. The courses outline and structure of the programme must be in a manner that is problem oriented and professional. The adult learning needs special attention to be paid (Knowles, 1980).As indicated by Dr. Livingston that: "As a rule, however, they like their learning activities to be problem centered and to be meaningful to their life situations, and they want the learning outcomes to have some immediacy of application. The past experiences of adults affect their current learning.... Finally, adults exhibit a tendency towards self-directedness in their learning" (Alikakos, 2015).Thus, it can be argued that: "The major emphasis in adult learning is on the practical rather than on the academic; on the applied rather than the theoretical; and on skills rather than on knowledge or information" (Johnstone et al., 1965). The participation of adults in legal education is quite familiar with society as the law supplements morality and values within society (Hussain, 2013). 
In this context, this paper is divided into IV Sections. Section I describes the significance of the legal education. Section II elaborates changing characteristics of legal education in Pakistan. It analyses the recent Judgment of the August Supreme Court and describes its declarations and directions. Section III explains the role of HEC and the PBC by comparing relevant provisions. Section IV discusses the challenges. Finally, recommendations will be given and conclusions will be drawn up.

\section{Legal Education}

The injunction of Islam clearly speaks for justice. The Holy Quran provides that:

"Be just: this is closest to being God-conscious" (Surah al-Maidah: 8). Another Ayat of Holy Quran provides that:

"O ye who believe! Stand out firm for justice, as witnesses to Allah, even as against yourselves, or your parents, or your kin, and whether it be (against) rich or poor: forAllah can best protect both. Follow not the lust of your hearts, lest ye swerve, and if ye distort (justice) or decline to do justice, verily Allah is well acquainted with all that ye do." (Verse 135) The Holy Quran has also highlighted socities that are destroyed because of inequality and injustice (Surah Yusuf 10.13).

The Constitution of Pakistan, 1973 provides in Preamble that: "freedom, equality, tolerance and social justice, as enunciated by Islam shall be fully observed" (Preamble). And that the State shall guarantee "fundamental rights including equality of status, of opportunity and before law, social, economic and political justice ..."; "wherein the judiciary shall be fully secured" and the State shall be based "on Islamic principles of social justice" that is further elaborated in the Principles of Policy that promise to ensure "inexpensive and expeditious justice" (Art. 37(d) of Constitution, 1973).

The Rule of Law and administration of justice is foundation of the Constitution of Pakistan. For enforcing rule of Law, the Judicature is required to safeguard the rights of the people of Pakistan and Constitution. The Judicature applies substantial as well as procedural law for resolving disputes among the people. The Judiciary is the main organ for interpretation of laws within country. However, the role of Bar and Bench is important for resolving disputes and for ascertainment of truth. The Bar has its own significance. The PBC is the regulatory authority for productive legal education. The Bar entry test is regulated by Legal Practitioners and Bar Councils Act, 1973(LPBCA, 1973). The PBC has various responsibilities including supervision, monitoring and implementation of standards of education across Pakistan. The legal education is important for learners and students as it helps them to know their basic rights provided by the law.

The Court has delivered significant Judgment for improving standards of legal education in Pakistan Bar Council vs. The Federal Government EOthers(PLD 2007 
SC394). The Court declared that"soundprofessional training and skill in both academic and vocational disciplines to beessential attributes for ensuring good advocacy".The legal education is not only for lawyers or related professionals rather it is necessary for other fields too. Even common man may have knowhow of his rights. However, an awareness to that extent is required. The legal studies may be enriched by technical, inter-disciplinaryand comparative approaches. Special efforts are needed for ensuring quality education across Pakistan. The next Section examines changing characteristics of legal education in Pakistan.

\section{Changing Characteristics of Legal Education in Pakistan}

The quality assurance in higher and legal education is a global phenomenon (Kanwal, 2007).In Pakistan, the developing and evaluation of quality of higher education is need of the hour. For achieving objectives of legal reforms, Pakistan is the country that faces certain challenges. There is slow improvement in quality assurance and higher education in Pakistan(Kanwal, 2007). There are certain organizational issues with regards to improvement in legal education in Pakistan. It is because of weak governance policies and quality assurance (Siddique, 2007). The recent judgment of SC of Pakistan is quite significant for changing characteristics of legal education in Pakistan. In this respect it is necessary to analyse the Judgment.

\section{Analysis of the Judgment of Supreme Court}

The Supreme Court of Pakistan has recently disposed of Constitution petition no. 134 of 2012 \&Civil misc. application no.1864 OF 2010 in Constitution petition no. 9 of 2005for the reasons to be recorded later and issued following directions and declarations. These are issued in light of the recommendationssubmitted by the Special Committee of PBC.

\section{Court's Declarations and Directions}

(i) The SC of Pakistan has directed that a Law Graduate Assessment Test (LAW-GAT) will be conducted by the HEC for law graduates on quarterly basis as an assessment test. It would be helpful for those who are willing to take license of the respective Bar; (ii) Similarly, an entry test titled Law admission test (LAT) will be conducted by the HEC for those who are going to take admission at legal institution. The outline of the LAT is also highlighted by the SC that includes objective type questions; (iii) The SC has also highlighted the recognized Universities/Institutions for awarding degree of Law;(iv)The Court has put Ban for conducting LL.M and $\mathrm{PhD}$ in Law classes on those institutions who are not in a position to start LL.B classes; (v) The Court has limited mushrooms admissions in LL.M and PhD programmes that are not fulfilling the requirements/criteria laid down by HEC; (vi) The Court directed that the HEC National Curriculum Review Committee (NCRC) in collaboration with sub-committee of PBC will design curriculum for admission into LL.B 5-yrs programme; (vii) The Court has also laid down the criteria for appointments in Law Faculties as per HEC criteria. The Court has directed to induct 
highly qualified persons for teaching at legal institutions; (viii) The Court has directed the affiliated colleges to constitute special sub-committees in relation to evaluation and inspection of unauthorized affiliated colleges and taking action of non-compliance; (ix) The Court has placed Ban on admission into LL.B 3-yrs programme after 31 December, 2018 and introduced five years programme to be followed by legal institutions; (x) The Court has put Ban on holding of LL.B evening classes across Pakistan; (xi) The Court has introduced special equivalence examination for law graduates who have completed their law degree from foreign institution. Such examination shall be taken by the HEC periodically and includes assessment of following subjects 1) Constitution of Pakistan; 2) Civil Procedure Code; 3) Criminal Procedure Code; 4) Qanoon-e-Shahadat and 5) Specific Relief Act. Such examination is limited to those who have taken their degrees from foreign institution; (xii) The Court has directed Bar Councils to introduce "Two Weeks BarVocational Course"during the apprenticeship to become and Advocate. However, it is argued that such a duration may be extended. of the six months training/pupillage period that alaw graduate intending to join the legal profession must undergo forbeing enrolled as an Advocate for practicing law; (xiii) The Courts has directed Federal and provincial Governments for allocation of Budget for promotion of legal education at all levels; (xiv) The Court has directed to pay responsible salary package and allowance of non-practicing to permanent faculty members; (xv) The Court has directed HEC to assess and examine the universities for evaluation of examination system in collaboration with PBC and the universities for improvement in legal education; (xvi) The Court has directed to establish autonomous Secretariat/Directorate of legal education in the PBC for standardizing quality legal education at all levels; (xvii)The Court has directed the PBC to constitute monitoring/implementation committee for the enforcement of directions; (xviii) The Court has listed and put ban on unauthorized law institutions for promotion of quality legal education; (xix) The Court has disaffiliated sub-standard law institutions; (xx) The Court has also directed to adjust ongoing students who are affected by disaffiliation by the concerned affiliated university/institution; (xxi) The Court has also highlighted weaknesses of existing law institutions that need improvements within six months; and (xxii) The Court has also barred to approach any other Court except the SC if any institution is aggrieved by these directions and declaration as a remedial forum. By giving detailed declarations and directions the Court has disposed of all misc. ancillary applications (C.M.A.No.1864 of 2010).It is argued that such directions are important for consideration by all institutions for improvement in legal education.As the HEC and PBC are regulatory authorities/legal education providers, it is necessary to examine their role by comparison to trace lacunas (if any).

\section{The Role of HEC and PBC}

The HEC and the PBC are responsible institutions for regulating legal education across Pakistan. The HEC is regulatory authority of all public/private sector universities whereas the PBC is statutory body for regulating legal profession. There are number of institutions that impart legal education. Even some colleges have affiliation with foreign universities. The role of HEC is like a facilitator for all 
universities. It has committee (NCRC) for making recommendations in consultation of members of the institutions and the PBC legal education committee for improvement in legal education. Based on these recommendations, curriculum for legal education is designed. The HEC has been given a broad mandate to develop and improve higher education and research. Good quality in higher education is an essential part of this. Therefore, the establishment of a quality assurance and accreditation system is one of the Commission's many important remits" (Report, 2006).

\section{The HEC}

The HEC is the sole authority for regulation and recognition of universities/institutions across Pakistan. It is also required to ensure quality assurance and promote higher education (Muhammad, 2011). The HEC has to ensure quality assurance, such as, to: "formulate policies, guiding principles and priorities for higher education institutions for the promotion of socio-economic development of the country" (Section 10 (1)(a) of HECO, 2002). The HEC is also responsible for "evaluation of the performance, and to prepare, through consultation with institutions, plans for development of higher education and express its opinion on all matters relating thereto"Section 10 (1) (b, c) of HECO, 2002).

\section{Quality Assurance Framework of HEC}

The vision and aim of HEC is "to develop a quality Higher Education System relevant to national needs and compatible to International Quality Assurance (QA) Standards that enables Higher Education Institutions to demonstrate excellence in teaching, learning and research". The HEC is also responsible for "recommending conditions under which institutions, including those that are not part of the state educational system, may be opened and operated"(Section 10 (1)(d) of HECO, 2002). The HEC has defined quality as follows:

"Quality in higher education is a dynamic entity which is the outcome of interaction among many factors including inter-alia, leadership, quality of faculty and students, infrastructure facilities, research and learning environment, governance, strategic planning, assessment procedures, and market force." Thus quality assurance is one of the objective and aim of the HEC. 


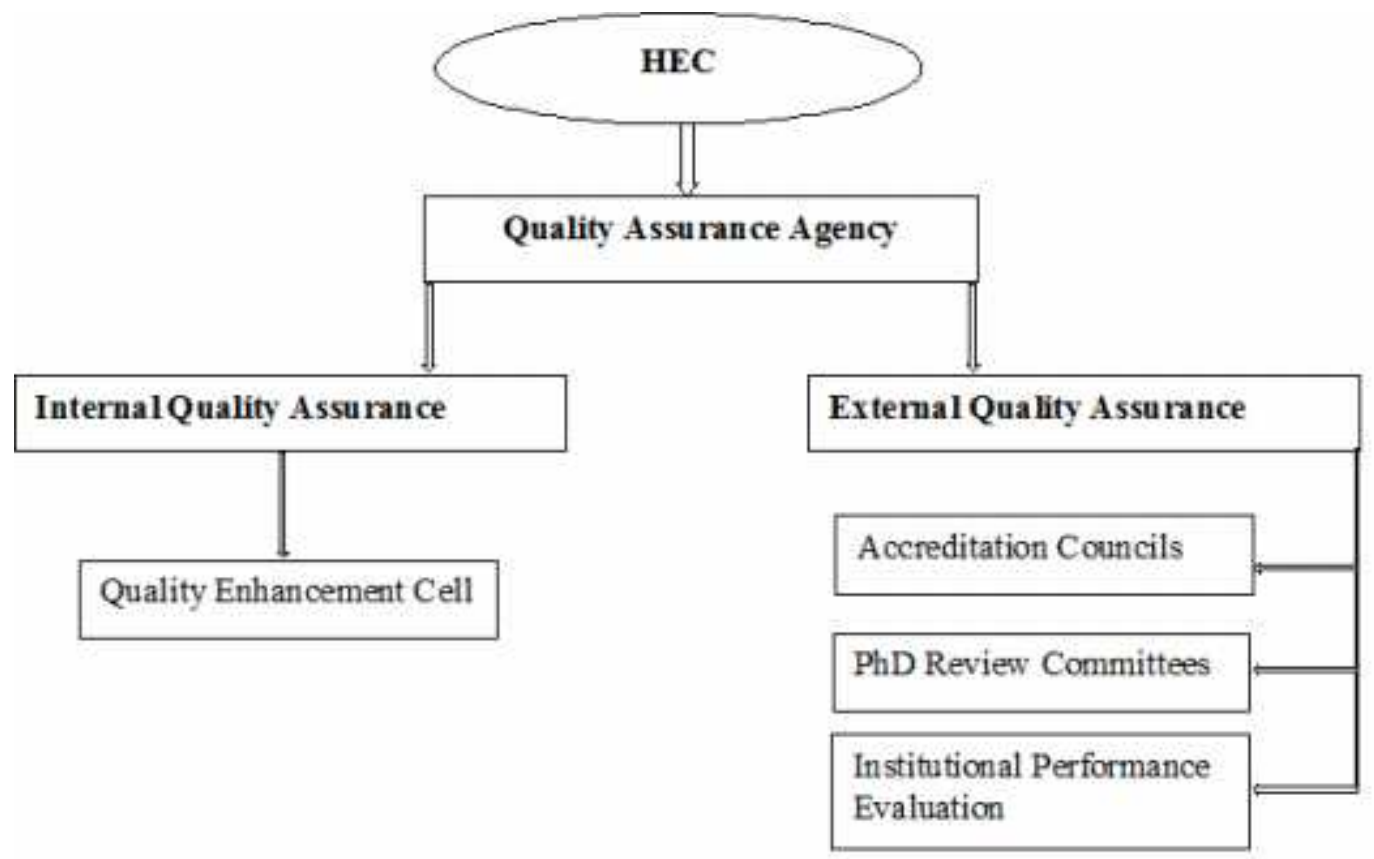

Figure 1: Quality Assurance Framework under HEC

For achieving quality assurance, the HEC has initiated steps for improvement in the education in Pakistan. The Higher education institutions are being set up and recognized by the HEC for achieving standard quality assurance. Various standards have been adopted for institutional performance as indicated in the figure below:

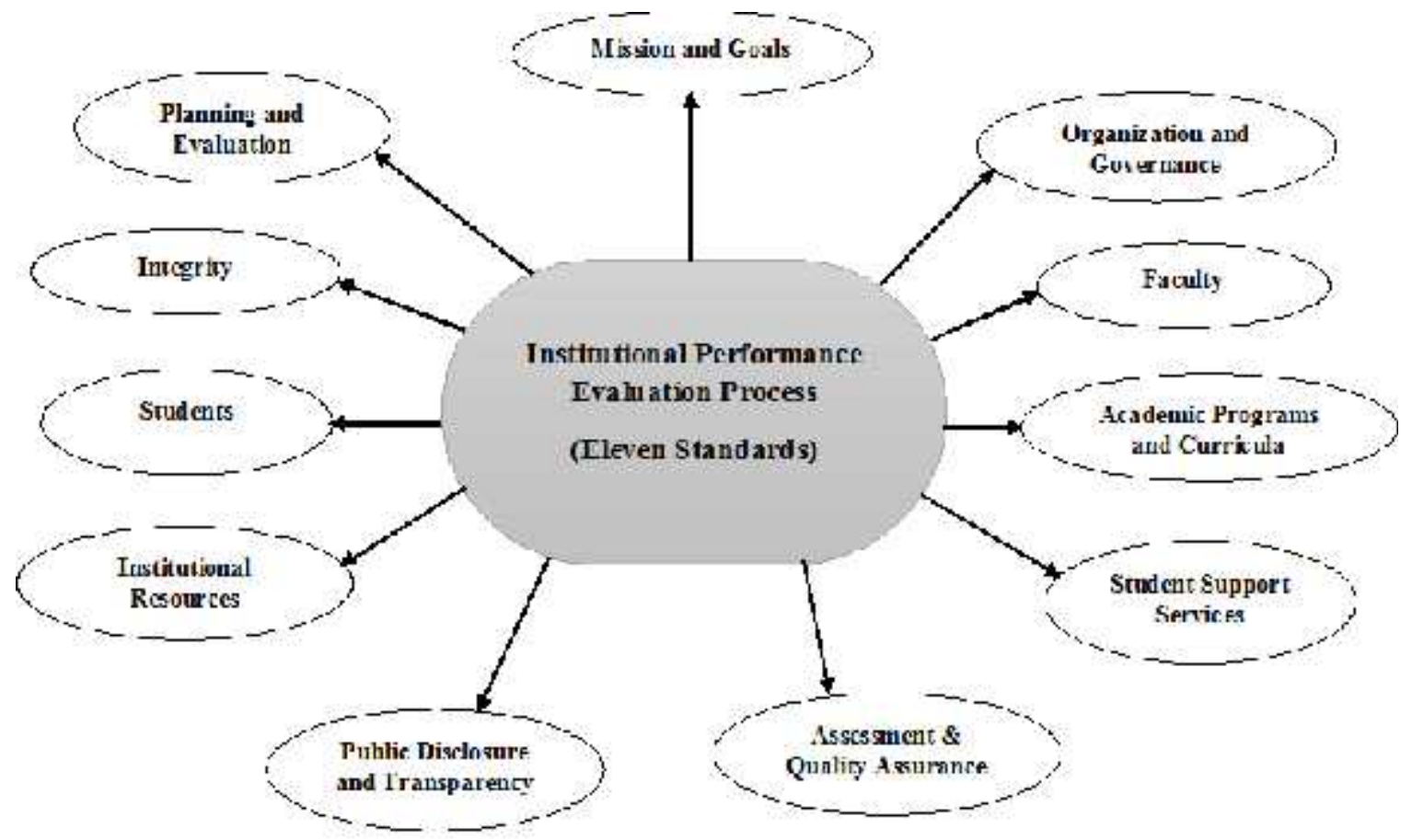


It is important to note that the HEC derives its power for making policies and recommendations for higher and quality education in institutions under section 10 of the HEC's Ordinance, 2002 whereas the PBC derives its power under Section 13(j) and $(\mathrm{k})$ of the Legal Practitioners andBar Councils Act, 1973, to promote legal education. The PBC also recognizes universities for imparting legal education across Pakistan (Khan, 2015).In this respect, the PBC has also framed the PBC legal Education Rules, 2015.

Such rules areimportant and relevant to criteria, recognition, inspection, degree awarding institutions, affiliations etc. The PBC has also constituted Special Committee for structural reforms in legal education by order dated 21.01.2018. Several commissions were formed, and committees were constituted for making recommendations. Later, these recommendations were examined during the proceedings held atthe Branch Registry at Lahore on 20.08.2018 and 24.08.2018 and at the PrincipalSeat on 28.08.2018. The recommendations were endorsed by the Court. It was an important step for furthering legal education. The recommendations are well thought out and have beenapproved by this Court with minor modifications.

\section{The PBC}

The PBC is also regulatory authority of the legal education in Pakistan. It derives its authority and powers from the Legal Practitioners and Bar Councils Act, (LPBCA, 1973) for ensuring appropriate standards of legal education and for requirements of license to be an Advocate across Pakistan. Also, the rules concerning legal education PBCLER, 2015 are important for consideration in this respect. The LPBCA, 1973, empowers the PBC to carry on activities for promotion of legal education in Pakistan (Sections 13, 26 (I) (iii) and 55 (q) of LPBCA, 1973. The provisions of the LPBCA, 1973 provides that any candidate who wants to join the profession of law or practice law must come up with degree in law from recognized University by HEC or foreign recognized universities. The degree in law is prerequisite for enrolling as an Advocate (Section 26 of the LPBCA, 1973).

The PBC has also power to make rules for legal education in Pakistan under Section 55 of the LPBCA, 1973. In this respect Section 55(q) provides that: "the PBC can set standards of legal education to be observed by universities in Pakistan and can conduct an inspection at the universities for that purpose". For achieving such purpose, the PBC has make rules commonly known as Pakistan Bar Council Legal Education Rules (PBCLER, 2015). These rules provide a comprehensive framework for legal education. For instance, these rules clearly define the syllabus required for a law degreeRule 7, Syllabus, PBCLER, 2015). Under such rules, "the duration of a law degree must not be less than five years" (Rule 6, PBCLER, 2015).The PBC is required to constitute special committees for inspection at universities/institutions across Pakistan. The members of the inspection team are required to examine quality assurance and improvement in legal education at various law institutions (Rule 14, Inspection, PBCLER, 2015).The institutions are required to follow rules of the PBC in 
letter and spirit otherwise the PBC has power to de-recognise or Ban the concerned institution if non-compliance has been made (Rule 19 (iii), PBCLER, 2015).Thus these rules are important for consideration and the concerned universities are required to follow such rules.

\section{Comparisonof the HEC and the PBC}

By comparing the role of both regulatory authorities, the HEC and the PBC, it can be argued that both bodies have their own authority, responsibilities and duties for promotion of legal education. The HEC is regulatory authority for all universities and responsible for quality assurance and standardize education in Pakistan whereas the PBC may instruct for quality assurance and may inspect various universities for examining quality assurance. The guidelines of the HEC are useful for all universities in Pakistan and it provides a general framework (Section 10 (1)(e) of HECO, 2002).The HEC has various committees for accreditation, equivalence, affiliation, inquiry and the NCRC for ensuring quality assurance.

The directives and guidelines of the HEC are binding on these committees (Section 13(1) 13(2) 10(1)(s) of HECO, 2002). On the other hand, the PBC has its committees for performing different jobs and for promotion of legal education. The PBC has constituted a separate legal education committee for supervising and improving legal education in Pakistan. The committee is responsible for supervision and looking into matters related to legal education in Pakistan. The PBC may constitute another committee if so required. The role of both regulatory authorities is quite well in manner. However, further improvements are required to achieve excellence and quality assurance of legal education (Shah, 2018).There is overlap between powers of both authorities in terms of jurisdiction as reflected in the figure below:

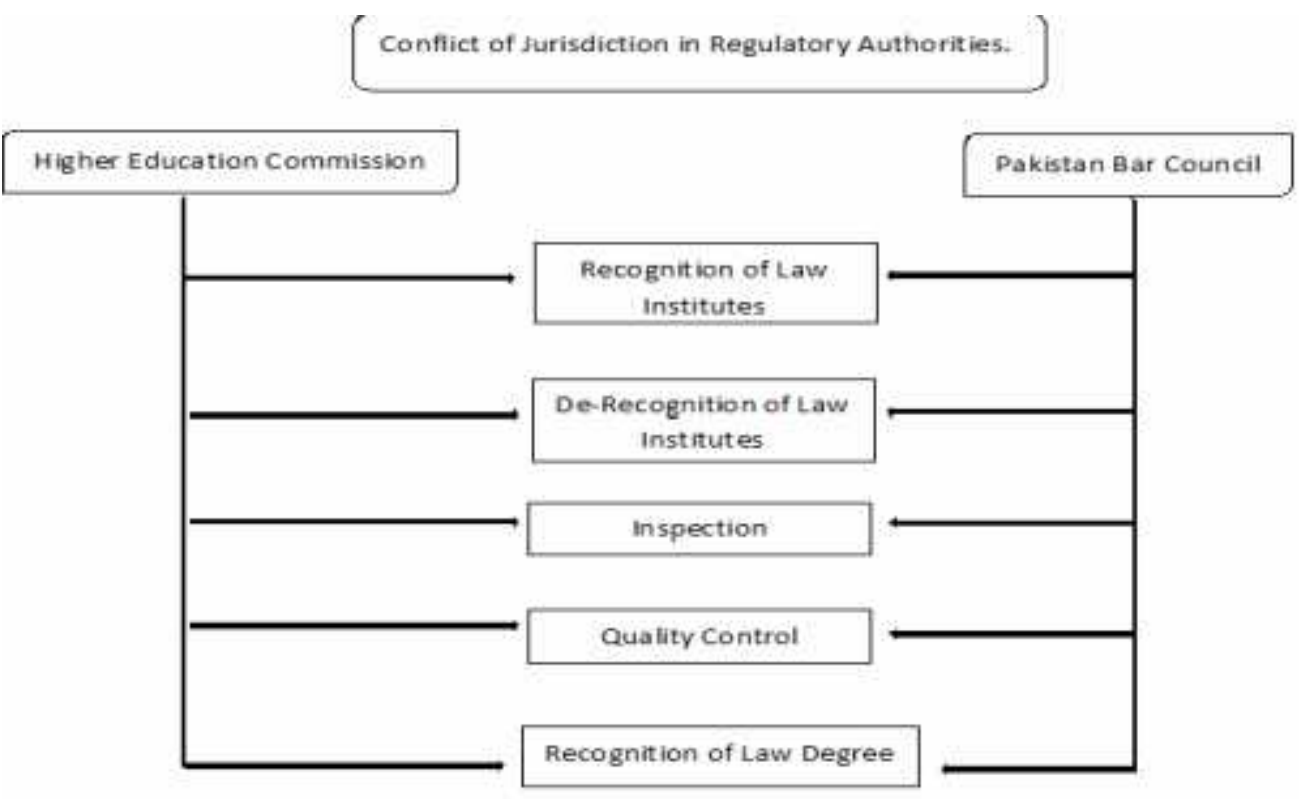


The both authorities have overlapping powers in relation to promotion of legal education. The legal system of Pakistan has certain strengths and weaknesses in terms of legal education. The strengths of the legal system includes rule of law, justice, fairplay, equality etc as envisaged in the Constitution, 1973. However, it is a big weakness and challenge to implement provisions of law in true sense. Special efforts are needed to overcome this problem of implementation. There is need oflegal as well as judicial education in order to aware people about their rightsand justice. As pointed out by Judge Oxner that judicial education, "pre-service or orientation program[me]s" and, second, "continuing judicial education and professional growth training" are essential for further progress (Oxner, 2003). She counts four levels of judicial education: "learning skills, understanding new laws, new intellectual approach in exercising judicial discretion, and bringing attitudinal change aimed at social accountability" (Oxner, 2003).The role of judicial education and its importance is nicely examined by KhurshidIqbal in his article (Iqbal, 2015). For analysis of HEC and PBC, an excellent contribution is written by Sardar Ali Shah et al, 2018).Thus,academic as well as practical training is required to strengthen the legal system and legal education in Pakistan.

\section{Challenges}

Although the August SC of Pakistan has given its verdict regarding reform inlegal education but still there are certain challenges. The judgment PLD SC 391 of 2007 is also important for consideration. The major challenges include:

(i) Active supervisions and monitoring by the HEC and the PBC;

(ii) Involvement of academicians in policy making;

(iii) Improvements in Quality assurance criterion;

(iv) Legal experts' opinion in designing of curriculum; and

(v) Implementation of the laws of regulatory authorities;

\section{Conclusions}

Supremacy of Rule of law and administration of justice are essential for progress in any country. As indicated by Raz that: "[T]he rule of law is just one of virtues which a legal system may possess and by which it is to be judged. It is not be confused with democracy, justice, equality (before the law or otherwise), human rights of any kind or respect for persons or for the dignity of man". He further argues that: "[i]t is said that the rule of law means that the government actions must be authorized by law" (Raz, 1979). The legal education is not only meant for lawyers but it is relevant for those people who "will go on to become social reformers, political leaders, human rights activists, legislators, legal draftsmen and jurists" (Rashid, 2016). 
As indicated by Khwaja, Zafar, Aslam and Hussain's that: “The quality assurance measures introduced in Pakistan are still in their infancy and need to be nurtured further. Some measures that need to be undertaken in the short term are granting of autonomy to QAA, introduction of a quality culture, induction of qualified professionals, and external review of programs by foreign experts. These steps would further help to attain international compatibility and competitiveness" (Khwaja et al, 2012).There is needed to further strengthen the legal education by taking special measures. The role of academicians as well as respective members of Bar and Bench and the HEC is important by taking serious steps towards promotion of legal education across Pakistan. The judgment of the SC in relation to legal education is quite important for consideration at all levels. However, implementation of the judgment is a big challenge. 


\section{References}

Alikakos, P. (2015). Joint initial and continuous training for judges and lawyers in theframework of the council of Europe and according to the Greek legal order.Journal of the International organization for judicial training.Issue 4, p117.

All-Pakistan Educational Conference, held in Karachi on 27th November, (1947).

Hussain, F. (2013).Continuing Legal/Judicial Education in Pakistan.FederalJudicialAcademy. Islamabad.

Introduction, Higher Education Commission Pakistan, Online available at:http://hec.gov.pk/english/services/universities/QAA/Pages/default.aspx.

Iqbal, K. (2015). The Rule of Law Reform and Judicial Education in Pakistan Search for a Model.European Journal of Law Reform. (17) 1. p48.

Johnstone, John W. C. \& Rivera, Ramon J. (1965).Volunteers for Learning. Chicago: Aldine Publishing Company.

Kanwal, A. (2007). Issues of quality assurance (QA) in LIS higher education in Pakistan.International federation of library associations and institutions (IFLA).

Khan, Ahmed A. (2015). Legal Education in Pakistan-A Review.Faculty of Social Sciences University of Peshawar.

Khwaja, Azam A. Zafar, F. Aslam, T. \&Hussain, A. (2012).Quality Assurance and Accreditation Practices in Pakistan.Archives Des Sciences 65, No. 7. pp224-229.

Knowles, M. (1980).The Modern Practice of Adult Education: From Pedagogy toAndragogy. Chicago; Follett.

Muhammad, P. (2011, March 27). 18th amendment: higher education commission. The Express Tribune.

NRIC (2006). Report on The System of Education in Pakistan, Nordic Recognition Information Centers

Oxner, Judge S.E. (2003). Judicial Education. The Philja Judicial Journal Vol. 15, No. 5. pp. 32-47.

Pakistan Bar Council Legal Education Rules. (2015). Rule 7, Rule 6,Rule 14, Rule 19(iii).

PLD 2007 SC 394 
Quality Assurance, Higher Education Commission, Pakistan. Online available at:http://www.hec.gov.pk/english/services/universities/QA/Pages/default.a spx.

Rashid, U. (2016). Problems with Legal Education in Pakistan: Are Pakistan Bar Council Legal Education Rules 2015 Enough? Courting the Law.

Raz, J. (1979). 'The Rule of Law and its Virtue', in The Authority of Law, Oxford, Clarendon. pp. 211-229.

Shah, Sardar A. Balasingam, U.\& Dhanapal, S. (2018).Legal Education in Pakistan: An Overview. 26 (2) IIUM Law Journal. p421.

Siddique, O. (2007). Marital Law and Lawyers: The Crisis of Legal Education in Pakistan and Key Areas of Reform. Regent J. Int'l L. 5. p95.

The Constitution of Islamic Republic of Pakistan.(1973).Art.175 (3), Art.37(d), Art.175 (3), Art.37(d).

The Higher Education Commission Ordinance. (2002). Section 10 (1)(a), Section 10 (1) $(b, c)$, Section $10(1)(b, c)$, Section $10(1)(d)$.

The Holy Quran, Surah al-Maidah: 8, Surah Yusuf 10.13.

The Legal Practitioners and Bar Councils Act.(1973). Sections 13, 26 (I) (iii), Section 55 (q), Section 26. 